\title{
Causes of Tightening Government Control of Universities
}

\author{
ERNEST SIRLUCK**
}

The relationship between universities and governments, particularly provincial governments, is changing. The change is taking place at different rates in the several jurisdictions, and in some places there may be counter-eddies to the main current, but in general there is a gathering thrust toward closer government control of universities. The trend manifests itself in varying ways, sometimes in the abolition of buffer mechanisms, sometimes in their transformation into control mechanisms, sometimes in contingent financing, sometimes in overt government intervention despite legalities, sometimes in subtler ways. The trend can be all too abundantly documented, but that would take too long; let me leave it as my perception of what is happening, and let us look at some of its causes.

During the boom period of the later 1950's and the first half of the 60's the universities were everybody's favorite instrument for the advancement, not only of knowledge and understanding, but also of the public weal. University education seemed almost a species of magic, a universal panacea, and there was a sustained public demand not only for instant expansion of what the universities had traditionally done but also for immediate extension into many new activities. The universities were caught up in the euphoria and co-operated willingly with most of these demands, perhaps not recognizing, or if they did, only very dimly, that they would be transformed in the process.

Governments, always happily responsive to taxpayers' demands for expansion, eagerly financed the boom. They were for the most part sensitive to the universities' concern that they not lose their autonomy in becoming bigger, more instrumental, and more costly. The Federal Government's growing contribution continued to be by way of per capita grants, which were entirely non-directive. Most provincial governments adopted policies of financial control only, and many established buffer commissions or separate university ministries, often both, in a deliberate effort to avoid slipping into control of the universities. Indeed, it was in good part in order to limit government influence that so many provinces with more than one university adopted formula financing.

Needless to say, the system did not function perfectly, and there were cases of government favoritism, particularly in the allocation of facilities, and government pressure, especially in the health manpower field. But it was not until the advent in the mid-60's of student militantism, with its multiple implications and consequences, that the intent to preserve the universities' autonomy began seriously to waver. For our purposes it is

*This article is based on an address given by Dr. Sirluck to a University of Toronto Convocation on June 11, 1974.

**President, University of Manitoba 
not important to distinguish among the negative public reactions; whether it was anger at the students for what was seen as ingratitude, irritation with the universities for their inability to maintain order, disappointment with them for their slowness or failure to reform, it all meant the end of the euphoria.

Next came the tightening of the high-level labour market, particularly in non-professional areas. With the spectacle of the unemployment or under-employment of significant numbers of university graduates, doubts began to be cast upon the economic value of university education, and hence upon the soundness of the public investment. Taxpayer demands began to be heard that the universities eliminate expensive "over-production" in the affected sectors, and when the universities, concerned both with the students' right of choice and with the notorious unreliability of manpower forecasts, seemed slow to respond, the taxpayer pressure was turned upon governments.

It is at this point that the negative implications of the 1967 Federal-Provincial costsharing Agreement on post-secondary education began to emerge. The constitutional assignment of education to provincial jurisdiction had not been a barrier to a Federal presence in the universities when the National Research Council began its support of university research in 1917, nor when the Federal Government began its direct grants to universities in 1951. But Premier Duplessis of Quebec saw within a year that these operating grants would make universities more autonomous, and since he didn't wish Quebec universities to be autonomous he ordered them, after the first year, not to accept the grants. For almost a decade Quebec universities had to forego the federal grants which their sister institutions in the rest of the country were receiving, until in 1959 a new provincial government worked out an arrangement with the Federal Government whereby a tax transfer between governments replaced direct grants to Quebec universities, thus enabling the Quebec government to increase its support of Quebec universities.

In 1967 the other provinces showed that they had learned a good deal from Quebec about how to deal with the Federal Government. We therefore have a federal-provincial cost-sharing agreement for post-secondary education, with the federal contribution, except in research, going in the form of tax transfers to the provincial governments, not to the institutions, and with the provincial governments entirely responsible for the determination of grants.

With the Federal presence in the universities thus removed except in research, and with the sharp and continuing decline of tuition as a factor in university revenue, the provincial governments emerged as the single dominant factor in university financing. They thus felt more directly responsible than heretofore for the universities, and as the latter grew less popular and more costly, they called upon them to reduce "overproduction," to "rationalize," to cut costs, and so forth. At the same time provincial governments greatly extended their own responsibilities in such fields as health and social policy, resource development, transportation, urban deterioration, rural depopulation, the north, native peoples, the environment, etc., and called upon universities for new research and teaching programs in these areas. Universities have responded promptly to the demand for new services, but slowly to the demand that they curtail old ones, which means that costs keep rising faster than the combined factors of enrolment and inflation. 
It is not out of perversity that universities are slow to reduce or eliminate underpopulated sectors, and otherwise to "rationalize." It is a much more difficult and forbidding task than governments think. For one thing, some disciplines are basic to liberal education and must be maintained for the sake of the whole, even if temporarily in low demand. Again, stop-and-go management is ruinous, both as to quality and cost, and forecasts of demand have been so unreliable that universities are reluctant to act upon them in matters of such gravity. Further, university costs are largely human costs about $80 \%$ of the typical university budget goes to salaries, wages, and benefits - and any suggestion of reduction in staff leads at once to organized defensive action. Finally, universities now have great difficulty making what are known as the "hard" decisions: those requiring a shift of resources away from one or more identifiable sectors. This is less the result of a failure of nerve than a symptom of the fragmentation and dispersal of power in today's university. There are a multitude of entities within the university empowered to wield a veto. Government by consent is not too difficult with respect to positive actions; it is quite another thing where retrenchment is concerned. But in today's university, decisions are only possible by something approaching universal consent. As for "rationalizing" between universities within a province, or between provinces within a region or in the country as a whole, this is to encounter range after range of further difficulty, with the additional handicap that here the universities do not possess even the legal authority to act - a temptation, of course, to governments to use their authority.

Already exasperated by the universities' apparent inability to reduce costs, provincial governments have recently become increasingly sensitive to the remaining direct relationship of the universities and the Federal Government through the continuing Federal program of direct grants-in-aid of research. Grants-in-aid, they argue, attract overhead costs, which are a charge on the universities' budgets and therefore on the provinces' (albeit $50 \%$ of such costs are automatically passed on to the Federal Government in the cost-sharing program). Besides, they say, the provinces have many urgent responsibilities for which research is needed and they cannot afford to have provincial institutions directing their attention and resources to esoteric areas of little provincial concern, while immediate problems receive too little attention. Most provinces are therefore demanding that federally-funded university research be brought under some degree of provincial control, sometimes specified as a requirement that research programs conform in general to provincial priorities, but sometimes as a demand that each major research project be approved by a provincial office. These demands have not yet been pushed home in faceto-face confrontation, and it is not clear how strongly the federal government will resist them, but the universities have become caught in the historic struggle for preponderance between the two levels of government.

There are in addition certain conditions within the universities which may offer occasion for provincial government intervention. One is the widespread fear that the universities are falling under U.S. domination, which has resulted in a sizeable demand from within the universities themselves for government intervention and control in the most sensitive of all areas, that of staff appointments. Committees for the Canadianization of Canadian Universities include strong contingents of faculty members and graduate students, as well as persons from the outside community, and there is a con- 
tinued clamour for government-imposed quotas and citizenship requirements on the ground that the self-governing universities are allegedly failing to protect the Canadian character of Canadian universities. So far, action with respect to appointment quotas has been limited to legislative committee hearings in a few provinces, and no bills have yet been introduced, but the issue is very much alive and matters may be taken a step further in the next legislative season.

Another condition which may easily occasion government intervention is the advent of unionization. The support staffs in many universities have been unionized for some time, and the unionization of academic staff appears to be making considerable headway in a number of universities. The conditions and sanctions of collective bargaining make strongly for government intervention. Most obvious is the strike: if it succeeds in closing the university down in whole or in part, or seems about to, there will be immense pressure even on a reluctant government - and not every government will be reluctant - to procure or force a settlement. In the university environment lockouts are less discussed, but if one took place it might bring even greater pressure upon government to intervene. If bargaining is stalemated, there will be representations to government to intervene to prevent a breakdown and strike. If the bargaining pushes the university beyond the limits of its grant, or if it presses upon government sensitivities (such as what the other institutions the government supports are paying), the government may feel that it should do what it may come to see as its "own" bargaining. Thus the tendency in collective bargaining to bring to the table the ultimate determiner of the resource flow coalesces with the pressure on government to keep public institutions working; and if intervention in collective bargaining takes place it is a real question whether the government can or will thereafter disengage.

There are many other factors impelling governments toward closer control of universities. There is not space to go into them here, but together they amount to a growing disposition on the part of governments to "co-ordinate" universities fully with other educational institutions - which means to make them simply the upper level of a fully integrated educational system thought to exist solely to serve society's needs as these are seen and interpreted by the government of the day. An ominous factor in this connection is that there is no longer an important deterrent in the form of a strong private sector. Many of what were originally private institutions survive and retain some of the trappings of independence, but not enough of the reality, having accepted and become dependent upon government financing, to deter governments from actions they might not have taken when the private sector was strong.

I think it evident from these considerations that government pressures on university autonomy are not likely to be short-lived or evanescent. What are the countervailing factors?

I fear they are not many. Short of the universities suddenly achieving the kind of adaptive coherence which would enable them autonomously to satisfy government and taxpayer demands - a transformation they show no signs of achieving - the main visible defences of university autonomy constitute a pathetically meagre catalogue. One is the continuing direct Federal presence in research. Another is the evidence that governments have not been successful managers of educational institutions; I think a large part of the public knows this, and many government officers know it. Hence their concern for 
the public good may make them reluctant to bring universities under direct government control. (Besides, observing the kind of criticism now incessantly directed against university administrators, they may be reluctant to become its targets.) Finally, there is the traditional conviction of the university community, and of some informed and concerned sections of the public, that autonomy is necessary to the university enterprise. Historically this has been a strong factor, but as I have already indicated, it may now be a diminishing one.

I believe that the universities must do all they can to keep these factors in being, to strengthen and to add to them, but I do not think they will over-balance the pressures toward greater government control of universities. We must therefore, I believe, accustom ourselves to apprehending autonomy as a relative thing. During the euphoric late 50's and early 60 's we came to think of university autonomy almost as an absolute, sacrosanct and inviolable; but that kind of autonomy, if it ever had any reality, is gone, and if we are not to lose all powers of self-governance we must learn to defend whatever elements of autonomy we are able to keep from the outstretched hands of government in the years ahead. This will be an unrelenting struggle, and will require the help of all the friends we can muster, but to the extent that we can preserve the elements of autonomy the universities will be able to seize upon the next change of fortune to recover what the present public mood is taking away.

Meanwhile, there is an especially urgent problem: the defence of academic freedom. We have been accustomed to thinking of university autonomy as the sole and sufficient guarantor of academic freedom, so much so that many university people scarcely distinguish between the two. But with its current and prospective diminution it is not evident that university autonomy will in the future be a sufficient guarantor of what seems likely to be an increasingly threatened academic freedom. If we believe, as I do, that academic freedom is the soul of the university, we must find additional means to support it, for as governments exercise increasing control over universities they will inevitably come under increasing pressure to control what is said and taught within universities.

I am not sure what the most promising sources of additional support for academic freedom are. It may be that as the danger grows more visible legislatures and courts will step in; I hope so but do not heavily count on it. The direct Federal presence in university research is a major positive factor: it encourages - it does not guarantee, but it has so far encouraged - the exercise of one of the three basic elements of academic freedom, and the freedom of research is a great buttress for the freedoms of teaching and learning. We must not allow the Federal Government to surrender or abdicate its direct role in university research, and we must persuade provincial governments that their concerns about this direct relationship are either groundless or can and will be met. Next, it is important to revive in the university community, and especially in students, a commitment to academic freedom. For the most part professors understand the meaning of academic freedom in their work, and the same is largely true of graduate and many senior undergraduate students; but students in their first or second years often fail to grasp its centrality. If we can get them to appreciate that academic freedom is the indispensable condition of a valid higher education, as contrasted to a program of brainwashing and indoctrination, I think they will become its defenders. 
Even more important, we must labour to make society understand that without academic freedom it will lose something it needs far more than it realizes: the free pursuit of truth and knowledge, as contrasted with their pursuit only within approved patterns, and criticism of society according to reason rather than according to the policies of the government of the day. If we can make significant numbers of the public apprehend the importance of this, we may be able to defend academic freedom through the years of diminished autonomy immediately ahead. 